\title{
APLIKASI PEMBELAJARAN DOA HARIAN UNTUK ANAK USIA DINI BERBASIS ANDROID
}

\author{
Bodi Santoso ${ }^{1}$, Okky Pebriyani ${ }^{2}$ \\ ${ }^{1,2}$ Teknik Informatika, Fakultas Teknik, Universitas Pamulang, Tangerang Selatan \\ E-mail: ${ }^{1}$ 3odisantoso@gmail.com
}

\begin{abstract}
ABSTRAK
Mempelajari doa harian merupakan salah satu kegiatan pembelajaran anak pada usia dini. Seperti kita ketahui ada berbagai macam buku pembelajaran mengenai doa harian, namun isi dari buku tersebut tidak bersifat interaktif dan menarik. Untuk membangkitkan motivasi minat belajar anak usia dini terhadap doa harian perlu dikembangkan suatu metode pembelajaran yang menarik dimanapun dan kapanpun mereka berada tanpa harus membawa buku tentang doa harian atau tidak harus menghabiskan banyak waktu berdiam diri di depan sebuah laptop dan personal komputer. Untuk mengatasi masalah tersebut, maka perlu diadakan perbaikan pada sistem yang sedang berjalan dengan membuat aplikasi pembelajaran doa harian untuk anak usia dini yang diharapkan dapat mendukung proses pembelajaran. Metode yang digunakan dalam penelitian ini adalah SDLC (system developmen life cyele). Beberapa tahapan dalam metode ini adalah analisis perancangan sistem dan implementasi. Pada penelitian ini dibuat suatu sistem aplikasi berbasis android, sehingga tujuan dari pembuatan sistem ini adalah pembelajaran doa harian menjadi lebih efektif dan menarik. Hasil penelitian ini berupa aplikasi pembelajaran doa harian untuk anak usia dini pada smartphon berbasis Android yang menyajikan doa harian dalam bentuk elemen teks, gambar dan suara yang dapat menarik perhatian anak - anak. Pada aplikasi ini juga terdapat kuis tentang doa harian anak yaitu kuis pilihan ganda dan kuis tebak gambar.
\end{abstract}

Kata kunci: Anak, Android, Doa Harian

\section{PENDAHULUAN}

Perkembangan teknologi informasi saat ini berkembang dengan pesat, kerena teknologi informasi merupakan teknologi yang menggabungkan Komputer dengan jalur komunikasi yang berkecepatan tinggi yang dapat membawa data, suara dan video

Teknologi tersebut dengan cepat memberikan perubahan besar terhadap gaya hidup manusia saat ini. Salah satunya adalah semakin banyaknya penggunaan smartphone terutama yang berbasis android. Karena android merupakan perangkat bergerak pada sistem operasi untuk telepon seluler yang berbasis linux[2]. Selanjutnaya android dapat dikatakan sebagai OS (Operating System) Mobile yang tumbuh ditengah OS lainnya yang berkembang dewasa ini. OS lainnya seperti Windows Mobile, i-Phone OS, Symbian, dan masih banyak lagi[3].

Dimasa sekarang ini, banyak kalangan anak usia dini yang menggunakan smartphone berbasis android untuk berkomunikasi dengan orang tuanya ataupun hanya sekedar hiburan, sedangkan aplikasi untuk pembelajaran sangatlah minim, khususnya mengenai aplikasi pembelajaran doa harian untuk anak usia dini, karena doa merupakan hal yang sangat penting dalam kehidupan sehari-hari [4]. doa juga merupakan ibadah yang merefleksikan permohonan pertolongan dan pengharapan kasih sayang seorang manusia sebagai hamba dengan menunjukkan sikap butuh dan tidak memiliki kuasa serta daya upaya dan kekuatan, kecuali atas pertolongan Allah SWT [5].

Mempelajari doa harian merupakan salah satu kegiatan pembelajaran anak pada usia dini. Seperti kita ketahui ada berbagai macam buku pembelajaran mengenai doa harian, namun isi dari buku tersebut tidak bersifat interaktif dan menarik, sehingga dapat menurunkan minat belajar anak usia dini terhadap doa harian. Untuk membangkitkan motivasi minat belajar terhadap doa harian perlu dikembangkan suatu metode pembelajaran yang menarik untuk anak usia dini dimanapun dan kapanpun mereka berada tanpa harus membawa buku tentang doa harian atau tidak harus menghabiskan banyak waktu berdiam diri di depan sebuah laptop dan personal komputer [5].

Berdasarkan latar belakang di atas pengembangan aplikasi pembelajaran doa harian untuk anak usia dini berbasis android sangat diperlukan, guna menunjang kegiatan pembelajaran yang kreatif, inovatif, dan menarik 
serta mempermudah proses pembelajaran anak usia dini dan menjadi media yang cocok bagi anak usia dini jaman sekarang [6]. Hasil yang diharapkan dari penelitian dan perancangan game edukasi ini adalah dapat menciptakan suatu model pembelajaran baru yang dapat memudahkan siswa dalam memahami pelajaran-pelajaran yang diajarkan. Beberapa penelitian sebelumnya banyak mengembangkan mengenai aplikasi mobile phone sebagai media pembelajaran dalam mempelajari pengertian ilmu hadis yang disertai dengan hadist pilihan, penelitian ini menggunakan pendekatan prototyping [7]. Penelitian [8] aplikasi pembelajaran hafalan doa dan hadits berbasis J2ME yang dibuat menggunakan Netbeans

\section{METODE PENELITIAN}

Analisis sistem merupakan penguraian dari suatu sistem informasi secara utuh kedalam bagian-bagian komponennya dengan maksud untuk mengidentifikasikan dan mengevaluasi permasalahan, kesempatan, hambatan yang terjadi, dan kebutuhan yang diharapkan sehinga dapat diusulkan perbaikan. Sistem yang diusulkan pada tahap pertama adalah mendifinisikan permasalahan yang terjadi. Permasalahan yang dihadapi dalam penelitian adalah bagaimana membantu anak usia dini untuk memahami dan menghapal doa harian.

Dalam tahap ini tentang masalah sistemnya yaitu banyaknya anak usia dini dalam menghafalkan doa harian masih menggunakan media buku sehingga kurang efektif. Dari permasalah di atas maka dibuatlah aplikasi pembelajaran doa harian untuk anak usia dini dengan menggunakan smartphone android yang dikemas dalam bentuk elemen, gambar, teks dan suara yang diharapkan dapat membantu dalam kegiatan pembelajaran, dan meningkatkan pemahaman anak usia dini terhadap doa harian dan membuat anak semakin tertarik untuk mempelajari doa harian sejak dini.

Pada tahap design (perancangan), adalah tahap perancangan spesifikasi mengenai struktur program, gaya, tampilan, dan kebutuhan material meliputi :
a. Menyusun alur aplikasi yang berupa flowchart.
b. Merancang UML.
c. Membuat Struktur Navigasi.
d. Merancang User Interface.

\section{Perancangan Alur (Flowchart/diagram alur )}

Aplikasi

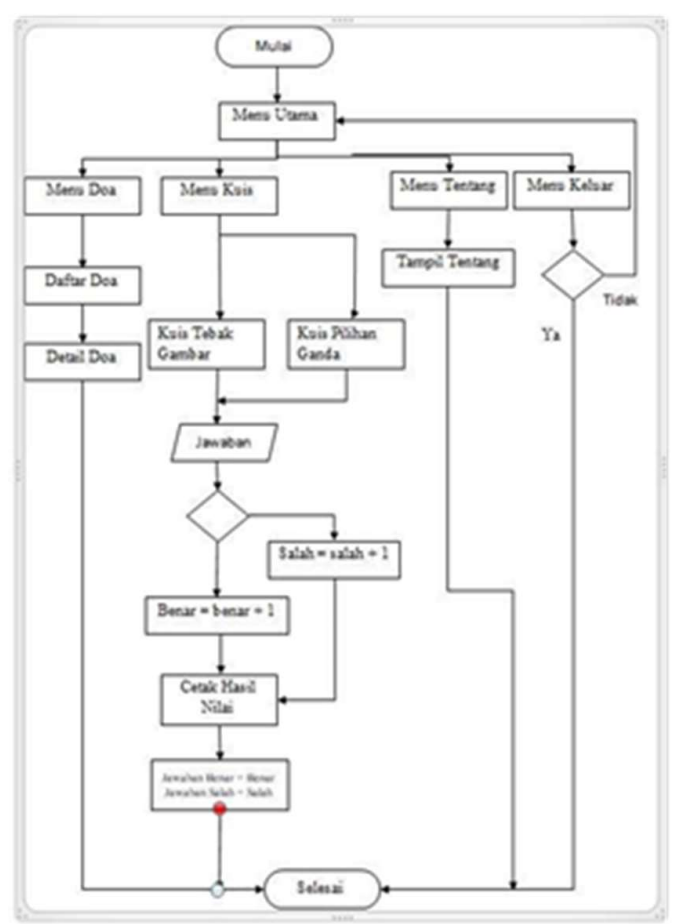

Gambar 1. Flowchart Aplikasi Doa Harian Anak

\section{Perancangan Unified Modelling Language (UML)}

Rancang sistem secara umum di lakukan dengan maksud untuk memberikan gambaran umum tentang sistem aplikasi doa harian anak usia dini. Rancangan ini mengidentifikasi komponenkomponen sistem informasi yang di rancang secara rinci.

\section{Use Case Diagram}

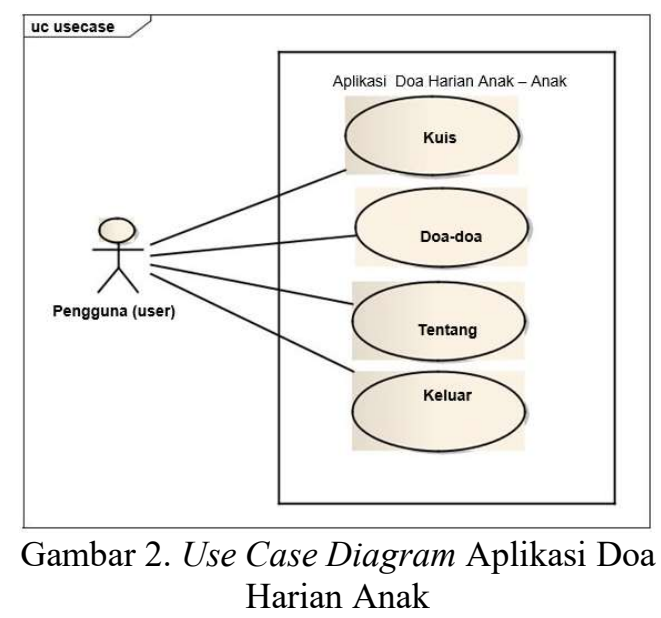

\subsubsection{Activity Diagram}

Activity Diagram memudahkan kita dalam memahami langkah-langkah aliran kerja, diagram ini memodelkan langkah kerja (workflow), dari use 
ISSN 2541-1004

case sehingga dapat diketahui siapa yang bertanggung jawab atas masing-masing aktivitas dan objek-objek yang yang di gunakan dalam aliran kerja.

a. Activity Diagram Menu Utama

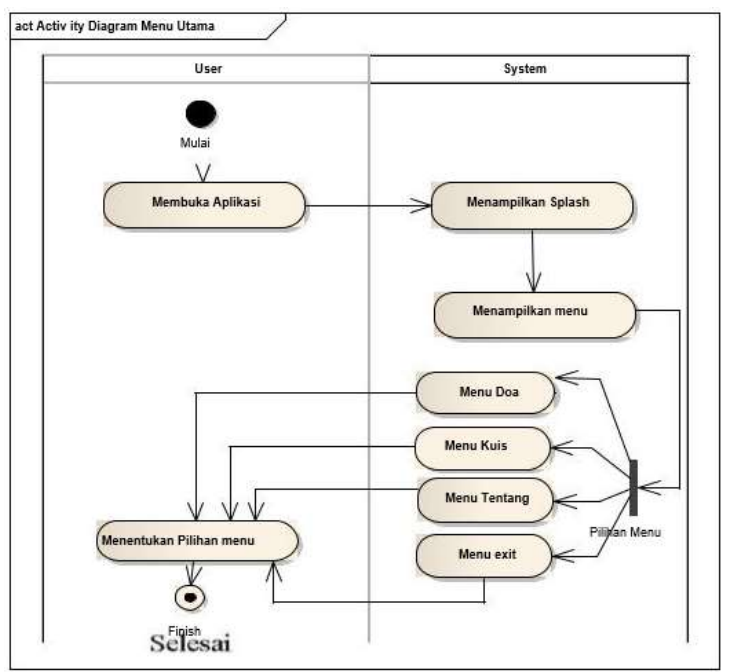

Gambar3. Activity Diagram Menu Utama Aplikasi

\section{b. Activity Diagram Menu Doa-Doa}

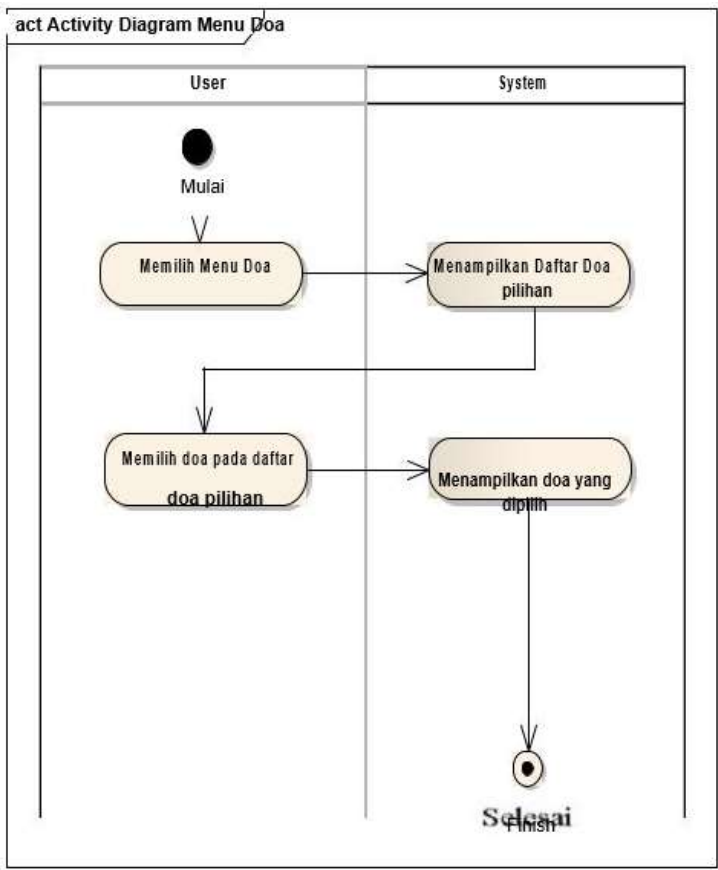

Gambar 4. Activity Diagram Menu Doa-Doa c. Activity Diagram Menu Kuis

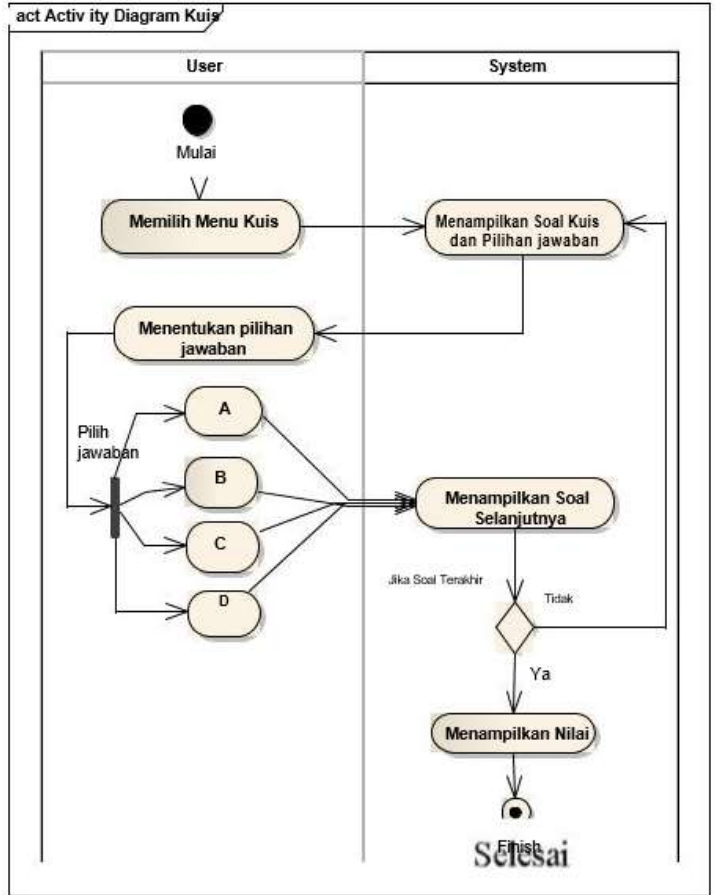

Gambar 5. Activity Diagram Menu Kuis

d. Activity Diagram Menu Tentang Aplikasi

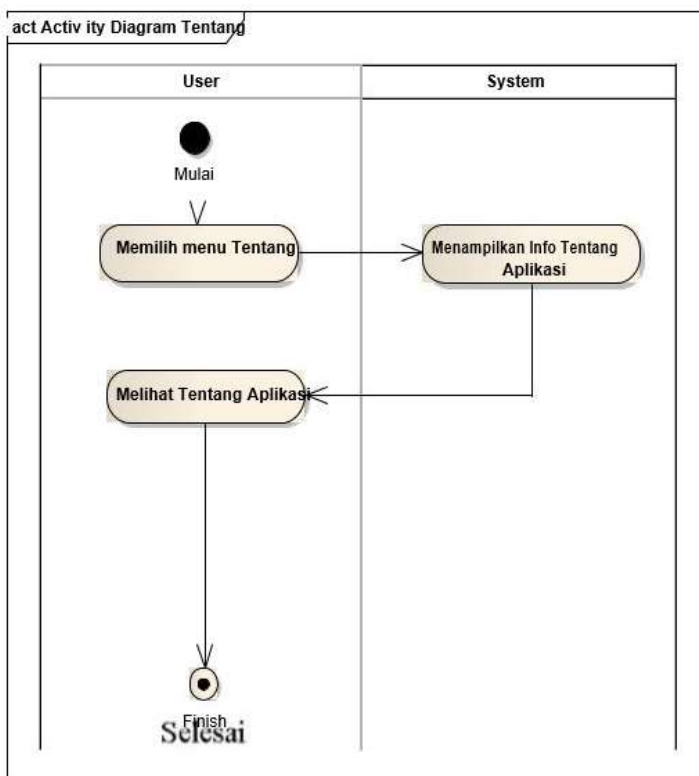

Gambar 6. Activity Diagram Menu Tentang Aplikasi

e. Activity Diagram Menu Keluar 


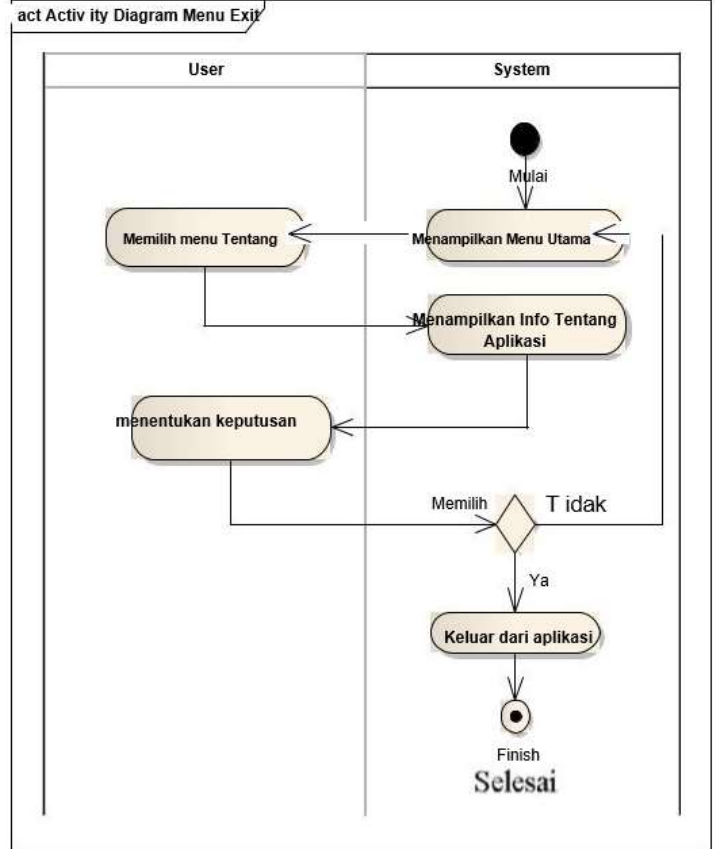

Gambar 7. Activity Diagram Menu Keluar Aplikasi

\section{Sequence Diagram}

a. Sequence Diagram Menu Doa

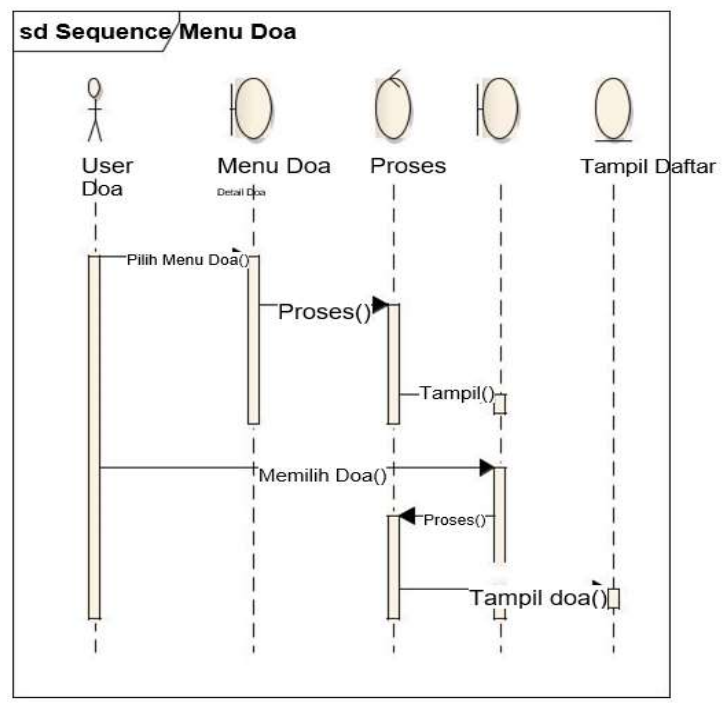

Gambar 8. Sequence Diagram Menu Doa

b. Sequence Diagram Menu Kuis

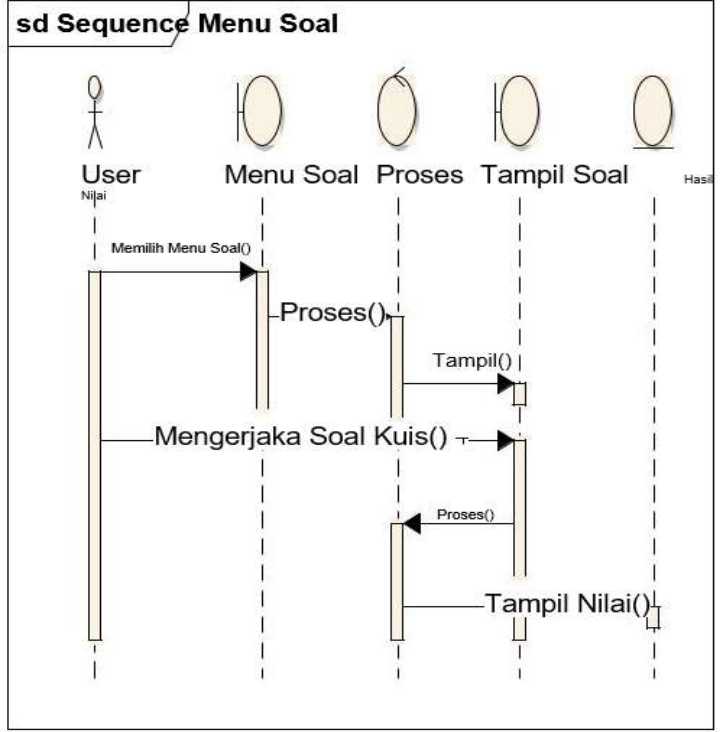

Gambar 9. Sequence Diagram Menu Kuis

c. Sequence Diagram Menu Tentang

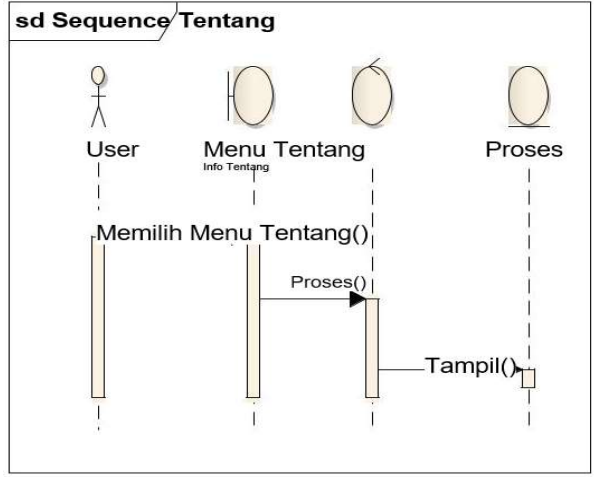

Gambar 10. Sequence Diagram Menu Tentang

d. Sequence Diagram Menu Keluar 


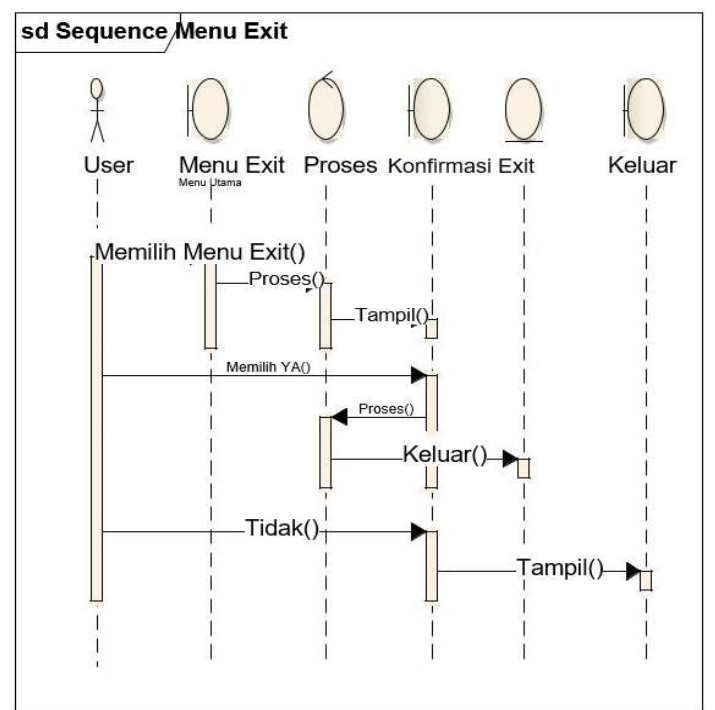

Gambar 11. Sequence Diagram Menu Keluar

\section{Struktur Navigasi}

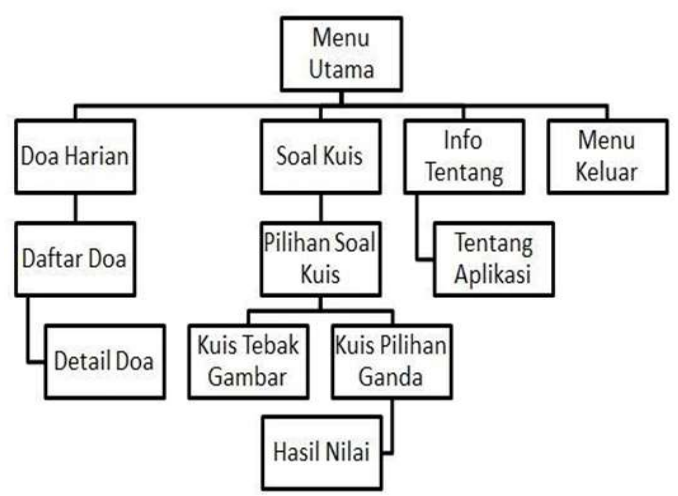

Gambar 12. Struktur Navigasi

\subsection{Perancangan Antarmuka}

a.Tampilan Menu Utama

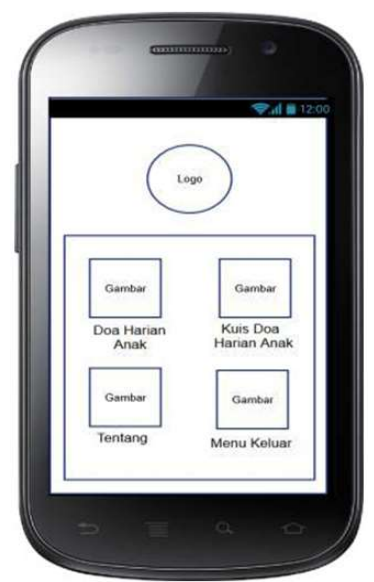

Gambar 13. Tampilan Menu Utama Aplikasi b. Tampilan Daftar Doa

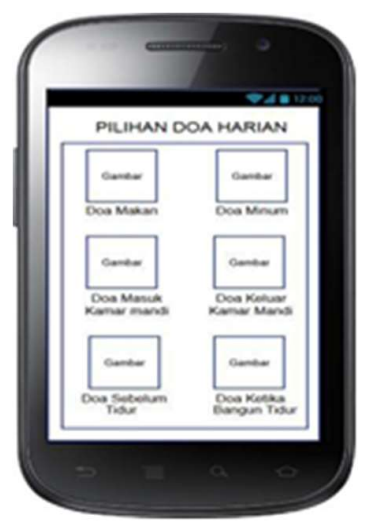

Gambar 14. Tampilan Daftar Doa Aplikasi

c. Tampilan Detail Doa

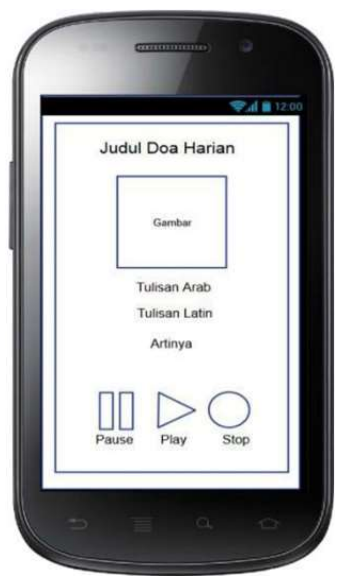

Gambar 15. Tampilan Detail Doa Aplikasi

d. Tampilan Pilihan Menu Kuis

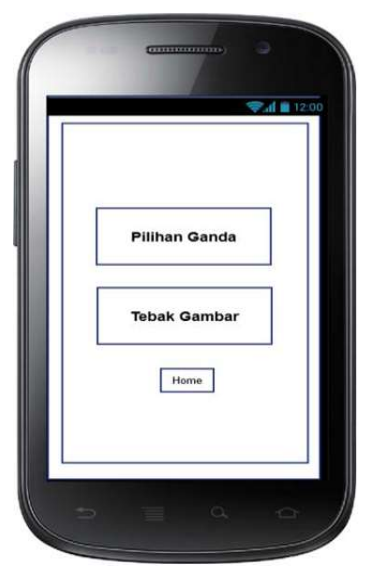

Gambar 16. Tampilan Menu Kuis 
e. Tampilan Kuis Pilihan Ganda

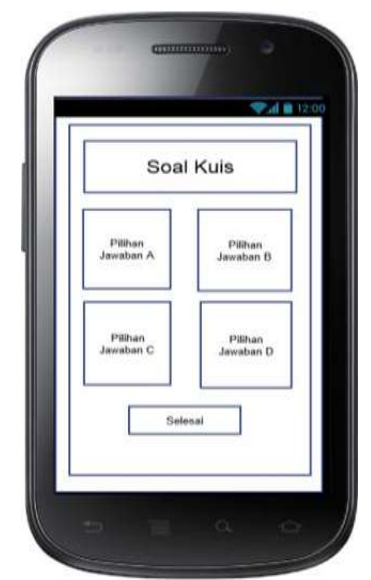

Gambar 17. Tampilan Kuis Pilihan Ganda

f. Tampilan Kuis Tebak Gambar

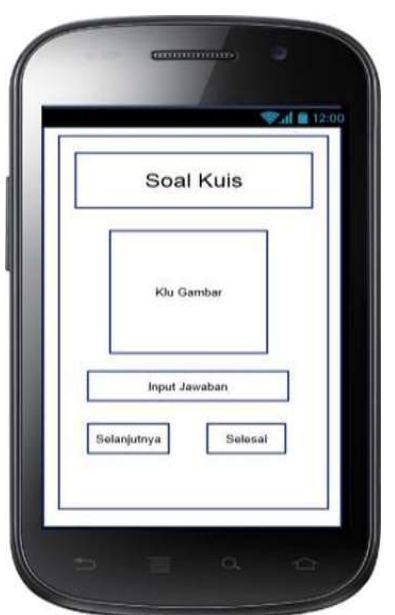

Gambar 18. Tampilan Kuis Tebak Gambar

g. Tampilan Hasil Nilai Kuis

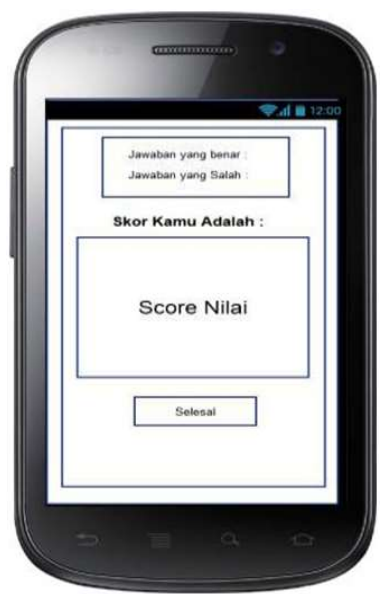

Gambar19. Tampilan Hasil Nilai Kuis Aplikasi h. Tampilan Menu Tentang Aplikasi

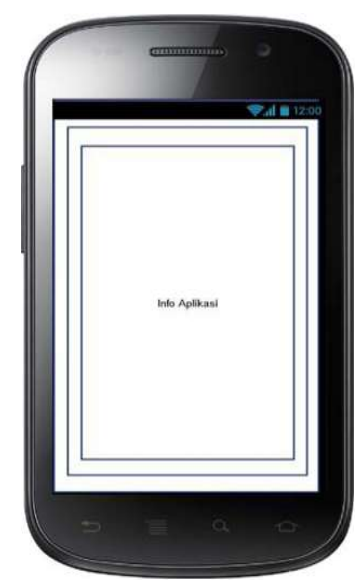

Gambar 20. Tampilan Menu Tentang Aplikasi

i. Tampilan Menu Keluar

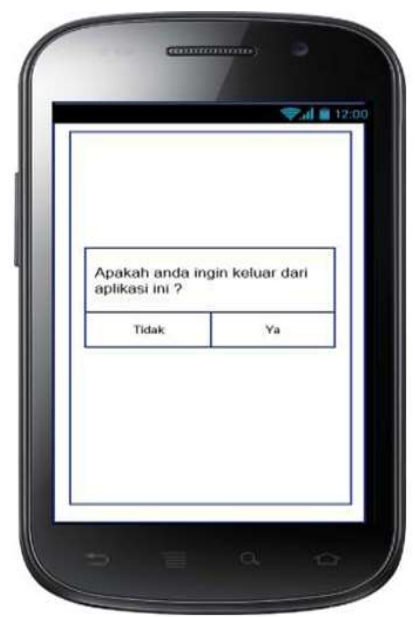

Gambar 21. Tampilan Menu Keluar Aplikasi

\section{HASIL DAN PEMBAHASAN}

Implementasi antarmuka akan menampilkan implementasi tampilan dari program aplikasi yang dibangun sesuai dengan perancangannya. Berikut adalah

implementasi antar muka aplikasi pembelajaran doa harian untuk anak usia dini berbasis android:

a. Gambar Tampilan Menu Utama 


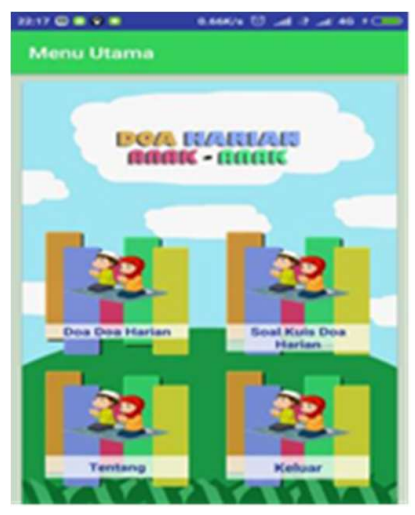

Gambar 22. Tampilan Menu tama Aplikasi

b. Tampilan Daftar Doa

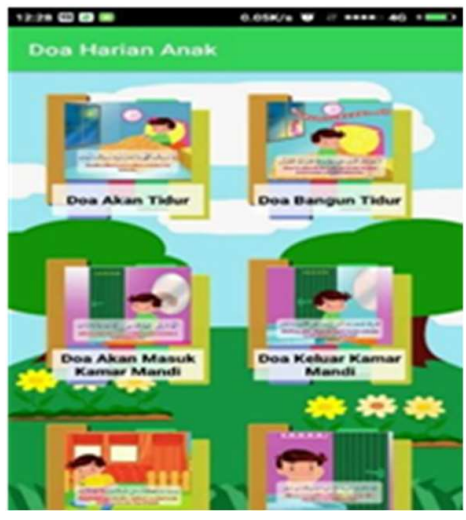

Gambar 23. Tampilan Daftar Doa

c. Tampilan Detail doa

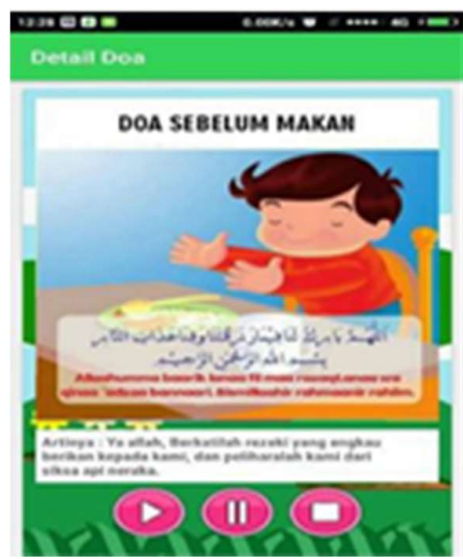

Gambar 24. Tampilan Detail Doa Aplikasi

d. Tampilan Pilihan Soal Kuis

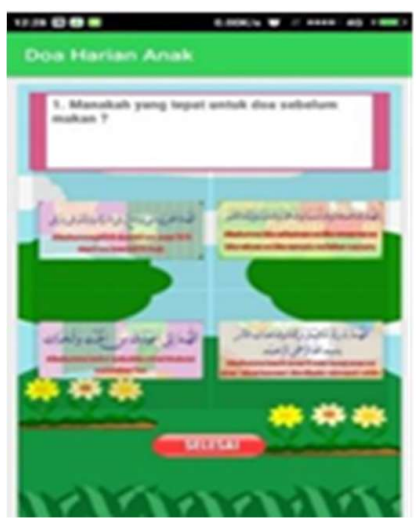

Gambar 25. Tampilan Pilihan Kuis Doa Aplikasi

e. Tampilan Soal Kuis Pilihan Ganda

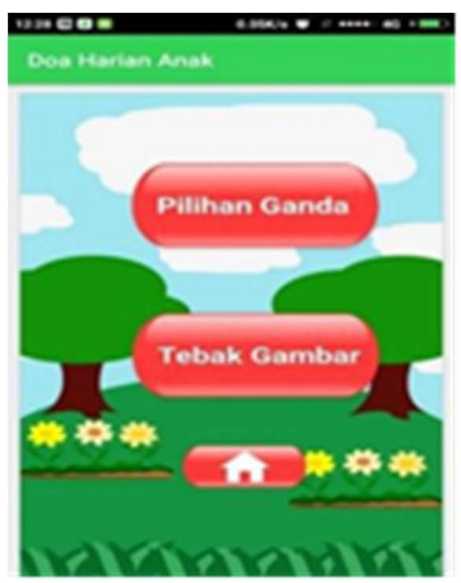

Gambar 26. Tampilan Kuis Pilihan Ganda Doa Aplikasi

f. Tampilan Soal Kuis Tebak Gambar

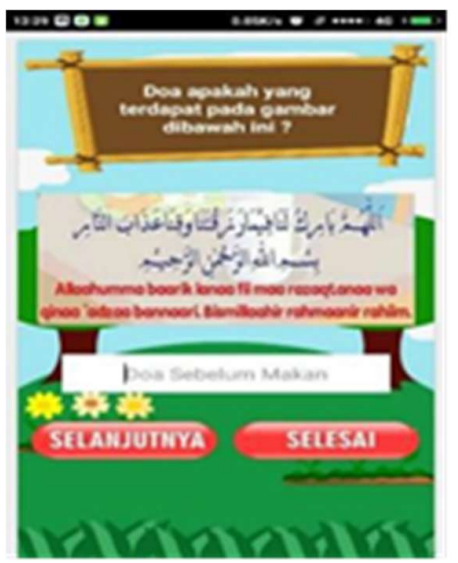

Gambar 27. Tampilan Kuis Tebak Gambar Doa Aplikasi 
g. Tampilan Hasil Nilai Kuis

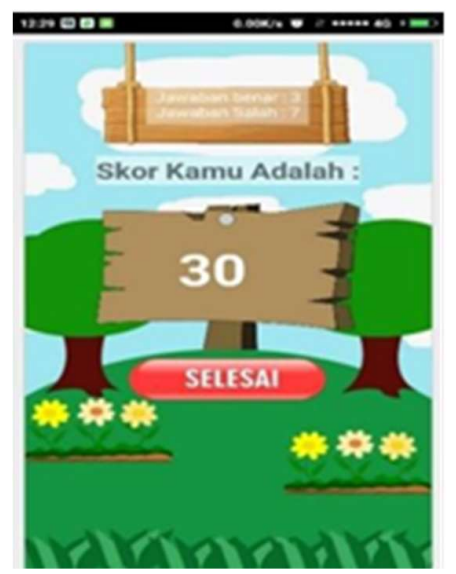

Gambar 28. Tampilan Hasil Nilai Doa Aplikasi

h. Tampilan Tentang

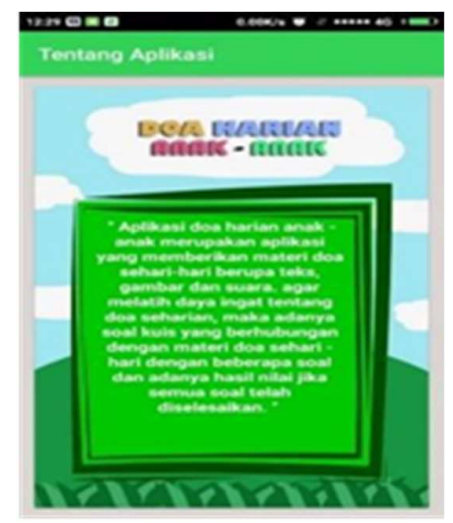

Gambar 29. Tampilan Tentang Doa Aplikasi

i. Tampilan Menu Keluar

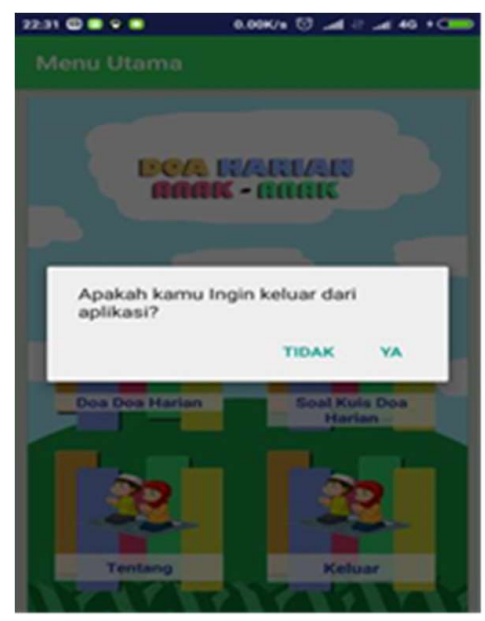

Gambar 30. Tampilan Menu Keluar Doa Aplikasi

\section{KESIMPULAN DAN SARAN \\ Kesimpulan}

perancangan aplikasi pembelajaran doa harian untuk anak usia dini berbasis android, membantu untuk menerapkan proses pembelajaran dengan cara yang lebih berbeda yaitu menggunakan smartphone tanpa perlu menggunakan buku doa-doa, sehingga penerapan pembelajaran doa harian terhadap anak menjadi lebih praktis.

Berdasarkan hasil pengujian dari berbagai golongan, menyatakan bahwa pembelajaran doa harian untuk anak usia dini berbasis android, lebih menarik minat anak-anak untuk belajar doa harian karena dalam aplikasi doa harian ini menampilkan warna-warna yang cerah, audio doa serta gambargambar yang mendukung dari setiap bacaan doa, sehingga proses belajar sangat menyenangkan dan tidak membosankan.

Aplikasi dalam bentuk android ini telah menampilkan banyaknya materi dan kuis soal berbagai doa-doa pilihan yang telah dipelajari atau yang diajarkan pada umumnya. Juga menyajikan hasil kuis soal berupa nilai, yang membantu anakanak untuk mengetahui kemampuan sampai mana anak tersebut memahami materi doa harian.

\section{Saran}

Aplikasi ini hanya sebuah aplikasi sederhana dan masih terbilang jauh dari sempurna. Diharapkan kedepannya ada pengembangan yang menjadikan aplikasi ini benar-benar lebih baik lagi, seperti. Adanya penambahan menu video doa harian agar proses pembelajaran doa harian anak lebih menyenangkan. Semoga aplikasi ini dapat dimanfaatkan sebaik-baiknya untuk membantu proses pembelajaran anak usia dini.

\section{DAFTAR PUSTAKA}

[1]. William dan Sawyer. 2003. Using Information Technologi. Yogyakarta: Andi.A

[2] Arifianto, Teguh. 2011. Membuat Interface Aplikasi Android Lebih Keren dengan LWUIT. Yogyakarta: Andi Publisher

[3] Hermawan S, Stephanus. 2011.Mudah Membuat Aplikasi Android. Yogyakarta: Andi Offset.

[4] Heru Supriyono, dkk. 2014. Rancang Bangun Aplikasi Pembelajaran Hadis Untuk Perangkat Mobile Berbasis Android. Jurnal Informatika Vol. 8, No. 2, Juli 2014907

[5] Muhammad Ismail Ishak. 2007. Ensiklopedia Do'a dan Dzikir. Jakarta: Penerbit Alifbata 
[6] Mulyanta, Leong Marlon.2009. Media Pembelajaran. Yogyakarta: Universitas Atmajaya.

[7] Amin Zarkasyi, Gesang Kristianto Nugroho, Media Pembelajaran Mengenal Komputer Sekolah Menengah Pertama kelas 1, Indonesian Jurnal on Computer Science - Speed (IJCSS) 13 - FTI UNSA Vol 9 No 2 - Agustus 2012, ISSN 1979 - 9330

[8] E.M.A, Fenty. Hanifa, Anif. Novi Rianto. 2014. Implementasi Algoritma Brute Force dan Fitur Location Based Sevice (LBS) Pada Aplikasi Kumpulan Doa Harian Berbasis Android. Program Study Teknik Informatika. ISSN: 2355-5920. UIN Syarif Hidayatullah Jakarta, Indonesia 